Saudi Journal of Medicine

Abbreviated Key Title: Saudi J Med ISSN 2518-3389 (Print) |ISSN 2518-3397 (Online)

\title{
Evaluation of Sexual Dimorphism in North India Population Using Morphometric Analysis of Foramen Magnum
}

Dr. Gaurav Katheriya ${ }^{1}$, Dr Nida Khan ${ }^{2}$, Dr. Vikram Khanna ${ }^{3 *}$, Dr. Ranjitkumar Patil ${ }^{4}$, Dr. Anurag Tripathi ${ }^{5}$, Dr. Vandana Singh $^{6}$

${ }^{1}$ Senior resident, Department of Oral Medicine \& Radiology Faculty of Dental Sciences, KGMU, Lucknow, India

${ }^{2}$ Senior Resident, Department of pediatric and preventive dentistry Faculty of Dental Sciences, KGMU, Lucknow, India

${ }^{3}$ Associate Professor Department of Oral Medicine \& Radiology Faculty of Dental Sciences, KGMU, Lucknow, India

${ }^{4}$ Professor \& Head Department of Oral Medicine \& Radiology Faculty of Dental Sciences, KGMU, Lucknow, India

${ }^{5}$ Additional Professor Department of Oral Medicine \& Radiology Faculty of Dental Sciences, KGMU, Lucknow, India

${ }^{6}$ Associate Professor Department of Oral Medicine \& Radiology Faculty of Dental Sciences, KGMU, Lucknow, India

DOI: $10.36348 /$ sjm.2019.v04i12.004

| Received: 07.08.2019 | Accepted: 20.08.2019 | Published: 25.12.2019

*Corresponding author: Dr. Vikram Khanna

\section{Abstract}

Objectives: The study was planned to evaluate the role of morphometric analysis of foramen magnum in determining sexual dimorphism. Also, we have compared the measurement of foramen magnum with age of individual. Material $\boldsymbol{\&}$ Methods: study was retrospectively and scans of CBCT were retrieved from archives of department. Length and width of foramen magnum in adults was measured. The data was statistically analyzed. Results: Mean length and width of foramen magnum was greater in males $(34.65 \mathrm{~mm}, 31.22 \mathrm{~mm})$ as compare to females $(33.59 \mathrm{~mm}, 30.11 \mathrm{~mm})$ and it was statistically significant $(\mathrm{p}<0.05)$. Mean length decreased in dimension i.e. from $35.22 \mathrm{~mm}$ to $33.73 \mathrm{~mm}$ as age progressed (18-60 years). Conclusion: Sexual dimorphism can be determined using foramen magnum dimensions. However, age estimation by morphometric analysis of foramen magnum requires more research.

Keywords: Sexual dimorphism, morphometric analysis, foramen magnum.

Copyright @ 2019: This is an open-access article distributed under the terms of the Creative Commons Attribution license which permits unrestricted use, distribution, and reproduction in any medium for non-commercial use (NonCommercial, or CC-BY-NC) provided the original author and source are credited.

\section{INTRODUCTION}

It is very strenuous to determine gender in anonymous skeletons. In explosions, warfare and other mass disasters, identification may be extremely difficult because of mutilation of skeleton [1]. The skull, pelvis and femora play a vital role in radiological determination of gender. Radiography can give accurate dimensions for which certain formulae can be applied to determine gender [2]. The length and the height of the head, the circumference of the head, the circumference of the occipital condyles and the foramen magnum (FM) have been used to determine gender in unidentifiable human remains [3-8].

The FM is an important landmark of the skull base that's why it has been a particular interest in anthropology, anatomy, forensic medicine and other medical fields. Catalina Herrera [9] indicated that the sagittal and transverse dimensions of the FM were significantly higher in human male than in human female skulls. Zaidi and Dayal[10] classified a sample of Indian skulls according to the shape and dimensions of the FM, reporting gender differences which were similar to those reported among Brazilian skulls[11].

The foramen magnum is the largest opening located in the median plane of the cranial cavity. The structure is completely surrounded by 4 principal components of the occipital bone, the supra-occipital part of the squama posteriorly, the basilar part anteriorly, and by two lateral parts on the right and left sides [12, 13]. These elements are connected by symmetrical posterior and anterior intra-occipital synchondroses. Fusion of the posterior synchondroses takes place at 2-4 years of age, while the anterior synchondroses start to fuse at the same age but continues until the age of 5-7[14]. The basilar part is also connected anteriorly with the body of the sphenoid bone by the spheno-occipital (sphenobasilar) synchondrosis, which disappears between the ages of 16-22 for males and 11-19 for females [15].

Variations of the shape of FM have got diagnostic, clinical and radiological importance [16, 17]. Also there exists some correlation between the shape of FM and ancestry of an individual. The 
dimensions of FM have clinical importance because the vital structures that pass through it may suffer compression as in cases of FM achondroplasia [18] and FM brain herniation [19, 20].

Present study, involves the assessment of morphometry, sexual dimorphism and age changes with the help of dimensions of foramen magnum in different subjects through CBCT imaging. This study may be plausible for the further use of CBCT imaging technology in forensics, as well as to further legitimize the aspect of foramen magnum in forensic sex determination.

\section{MATERIALS AND METHODS}

This study was carried out in the Department of Oral Medicine and Radiology, King George's Medical University, Lucknow, India. The study was retrospective study performed after deleting individual's name from the scans. The measurements of foramen magnum were performed prospectively on CBCT scan of 200 subjects. Only high-quality reconstructed images were selected. Low quality images with blurring or artifact caused by metallic objects and scans that were not covering the entire extent of the foramen magnum were excluded also, scans of subjects with history of trauma, surgery or any other pathological lesion (congenital/acquired).

The cone beam images were performed using Care stream 9300 CS CBCT machine. The patient was placed in a position so that the Frankfort horizontal plane was perpendicular to the head to obtain a consistent orientation of sagittal images. The CBCT images were obtained at $90 \mathrm{Kvp}, 4 \mathrm{~mA}$ for 6.3 seconds at FOV $(17 \times 6)$ voxel size of 200 . After the completion of raw data, the subject left the examination room and the radiologist was able to perform the primary reconstruction. After data collection, the data was analyzed statistically.

\section{RESULTS}

The demographic data showed that the present study population was $200(n=200)$, males were $55 \%$ out of which mostly were in the age group of 21-35 years however females were $45 \%$ out of which mainly were in 21-35 years age group. The unpaired t-test was performed to evaluate the comparison between dimensions of foramen magnum with age and sex.

It was observed that length of foramen magnum varied from $26.8-42 \mathrm{~mm}$ with mean length of $34.17 \mathrm{~mm}$ and on the other hand width of foramen magnum varied from $24.5-39.7 \mathrm{~mm}$ with mean length of $30.72 \mathrm{~mm}$.

On comparing the mean length of foramen magnum with gender, it was found that mean length was greater in males $(34.65 \mathrm{~mm})$ as compare to females $(33.59 \mathrm{~mm})$ and it was statistically significant $(\mathrm{p}<0.05)$ where as on comparing the mean width of foramen magnum with gender, it was found that mean width was greater in males $(31.22 \mathrm{~mm})$ as compare to females $(30.11 \mathrm{~mm})$ and it was statistically significant $(\mathrm{p}<0.05)$.

On comparing the mean length of foramen magnum with age of individual, it was observed that as the age progressed, mean length decreased in dimension i,e subjects below 18 years had the highest $(35.22 \mathrm{~mm})$ while subjects above 60 years had the lowest $(33.73 \mathrm{~mm})$ however it was not found to be statistically significant. On contrary, on comparing the mean width of foramen magnum we couldn't find the same findings as found in mean length. The subjects between 36-60 years had the highest mean width $(30.93 \mathrm{~mm})$ where as lowest found in subjects below 18 years $(30.06 \mathrm{~mm})$ and it was not significant.

\section{DISCUSSION}

In explosions, warfare, and other mass disasters like aircraft crashes, recognition and sex determination is not simple. The study of anthropometric characteristics is of primary importance while solving troubles related to identification. Craniometric features are included among these characteristics, which are closely connected to forensic medicine since they can be used to aid in identifying an individual from a skull found detached from its skeleton[21].

In the field of forensics, the study of anthropometric characteristics is of vital importance when resolving problems related to identification and documentation. Next to the pelvis, the skull is used for sex determination; however the determination of the sex from skull is not reliable until puberty [22]. Interestingly, compared to other skeletal elements, the foramen magnum reaches its adult size rather early in childhood [23] and is therefore unlikely to respond to significant secondary sexual changes thereby explaining the degree of sexual dimorphism of foramen magnum dimensions. Also biomechanically, there is no musculature acting upon the shape and size of the foramen magnum, making its principal function to allow the passage of vital structures into and out of the cranium, particularly the medulla oblongata, which occupies the greatest proportion of the foraminal space [24]. Since the nervous system develops and reaches maturity at a very young age in comparison to other body systems, it imparts no change in the dimensions of the foramen magnum. This is evidenced by the completion of fusion of the different elements of the occipital bone by 5-7 years of age and completion of fusion in the $\mathrm{C} 1$ centres by 5-6 years of age[25].

Variability in the size and shape of the FM has been described by many studies in the literature [2629]. Catalina-Herrera et al.[30] revealed significant differences between males and females for sagittal and transverse diameters of the FM and the values of males 
were larger than those of females. Gapert et al.[24] demonstrated statistically significant differences between males' and females' skulls in FM dimensions using discriminant function and regression analysis in an eighteenth and nineteenth century British sample. In contrast, different studies have not found significant sexual dimorphism in the diameters of the FM[26,31]. The aforementioned studies were performed with dry skulls. However, radiologic images provide several measurements without a flesh barrier and imaging methods are generally preferred by forensic scientists [22,32-35].

Uysal et al. showed that the length and width of the condyle and width of FM diameters were larger in males than in females in a Turkish population. They found statistically significant differences between males and females for width of FM diameters [32], with accuracy of $81 \%$ in determination of sexual dimorphism. Murshed et al.[27] evaluated FM dimensions using spiral CT and found that sagittal and transverse diameters and also area of the FM were significantly greater in males than in females for a Turkish population. Uthman et al.[22] measured sagittal and transverse diameters, area, and circumference of the FM in an Iraqi population and reported that the examination of the FM on CT scans can provide valuable measurements and these images could be used for sexual dimorphism when other methods are inconclusive. Abdel Karim et al.[36] revealed that the length and width of the FM are significantly larger in males than in females for an Egyptian population. Ilgüy et al.[33] found that the accuracy rate of FM measurements was $87.4 \%$ in females and $77.3 \%$ in males, with an overall accuracy rate of $83.2 \%$ on CBCT images in sex determination of a Turkish population.

Where as in the present study it was observed that that length of foramen magnum varied from 26.8$42 \mathrm{~mm}$ with mean length of $34.17 \mathrm{~mm}$ and on the other hand width of foramen magnum varied from 24.5$39.7 \mathrm{~mm}$ with mean length of $30.72 \mathrm{~mm}$.

On comparing the mean length of foramen magnum with gender, it was found that mean length was greater in males $(34.65 \mathrm{~mm})$ as compare to females $(33.59 \mathrm{~mm})$ and it was statistically significant $(\mathrm{p}<0.05)$ where as on comparing the mean width of foramen magnum with gender, it was found that mean width was greater in males $(31.22 \mathrm{~mm})$ as compare to females $(30.11 \mathrm{~mm})$ and it was statistically significant $(p<0.05)$.So, this study enlighten the role of foramen magnum in sexual dimorphism.

No other study in current literature emphasized on the age relation with the dimensions of foramen magnum except this study which states that as the age progressed, mean length decreased in dimension i,e subjects below 18 years had the highest $(35.22 \mathrm{~mm})$ while subjects above 60 years had the lowest (33.73mm) but it was not significant. Thus, to some extent we could say that there was some correlation of length of foramen magnum with age. But On contrary, on comparing the mean width of foramen magnum we couldn't find the same findings as found in mean length. The subjects between 36-60 years had the highest mean width $(30.93 \mathrm{~mm})$ where as lowest found in subjects below 18 years $(30.06 \mathrm{~mm})$ and it was not significant.

Thus, more studies should be done for finding the correlation between age and dimensions of foramen magnum. Therefore, the present study was pioneer study in itself which emphasizes the age with dimensions of foramen magnum and hopefully it enlightens anthropologists, morphologists and clinical anatomists.

\section{REFERENCES}

1. Holland, T. D. (1989). Use of the cranial base in the identification of fire victims. Journal of Forensic Science, 34(2), 458-460.

2. Di Vella, G., Campobasso, C. P., Dragone, M., \& Introna, F. (1994). Skeletal sex determination by scapular measurements. Bollettino-societa italiana di biologia sperimentale, 70, 299-299.

3. Quatrehomme, G., Fronty, P., Sapanet, M., Grévin, G., Bailet, P., \& Ollier, A. (1996). Identification by frontal sinus pattern in forensic anthropology. Forensic science international, 83(2), 147-153.

4. Günay, Y., Altinkök, M., Cagdir, S., \& Kirangil, B. (1997). Gender determination with skull measurements. J Forensic Med, 13(13-19), 4-8.

5. Günay, Y., Altinkök, M., Çagdir, S., \& Sari, H. (1998). Is foremen magnum size useful for gender determination? Bull Legal Med, 3(2), 41-45.

6. Cameriere, R., Ferrante, L., Mirtella, D., Rollo, F. U., \& Cingolani, M. (2005). Frontal sinuses for identification: quality of classifications, possible error and potential corrections. Journal of forensic sciences, 50(4), 770-773.

7. Rogers, T. L. (2005). Determining the sex of human remains through cranial morphology. Journal of Forensic Science, 50(3), 18.

8. Gruber, P., Henneberg, M., Böni, T., \& Rühli, F. J. (2009). Variability of human foramen magnum size. The Anatomical Record: Advances in Integrative Anatomy and Evolutionary Biology, 292(11), 1713-1719.

9. Catalina-Herrera, C. J. (1987). Study of the anatomic metric values of the foramen magnum and its relation to sex. Cells Tissues Organs, 130(4), 344-347.

10. Zaidi, S. H., \& Dayal, S. S. (1988). Variations in the shape of foramen magnum in Indian skulls. Anatomischer Anzeiger, 167(4), 338-340.

11. Manoel, C. C., Prado, F. B., Caria, P. H. F., \& Groppo, F. C. (2009). Morphometric analysis of the foramen magnum in human skulls of Brazilian 
individuals: its relation to gender. Brazilian Journal for Morphological Sciences.

12. Narkiewicz, O., Dziewiątkowski, J., Kowiański, P., Wójcik, S., Spodnik, J.H. (2010). Head. In: Narkiewicz O, Moryś J eds. Human anatomy. PZWL, Warszawa, 83-265.

13. Scheuer, L., Black, S. (2000). Developmental juvenile osteology.Academic Press, London.

14. Tillmann, B., \& Lorenz, R. (1978). The stress at the human atlanto-occipital joint. Anatomy and Embryology, 153(3), 269-277.

15. Shirley, N. R., \& Jantz, R. L. (2011). Sphenooccipital synchondrosis fusion in modern Americans. Journal of forensic sciences, 56(3), 580-585.

16. Gruber, P., Henneberg, M., Böni, T., \& Rühli, F. J. (2009). Variability of human foramen magnum size. The Anatomical Record: Advances in Integrative Anatomy and Evolutionary Biology, 292(11), 1713-1719.

17. Murshed, K. A., ÇİÇEKCİBAŞI, A. E., \& TUNCER, I. (2003). Morphometric evaluation of the foramen magnum and variations in its shape: a study on computerized tomographic images of normal adults. Turkish Journal of Medical Sciences, 33(5), 301-306.

18. Hecht, J. T., Horton, W. A., Reid, C. S., Pyeritz, R. E., \& Chakraborty, R. (1989). Growth of the foramen magnum in achondroplasia. American journal of medical genetics, 32(4), 528-535.

19. Reich, J. B., Sierra, J., Camp, W., Zanzonico, P., Deck, M. D., \& Plum, F. (1993). Magnetic resonance imaging measurements and clinical changes accompanying transtentorial and foramen magnum brain herniation. Annals of Neurology: Official Journal of the American Neurological Association and the Child Neurology Society, 33(2), 159-170.

20. Ropper, A. H. (1993). MRI demonstration of the major features of herniation. J Neurol Neurosurg Psychiatry, 56, 932-5.

21. Krogman, W. M. Is! can, MY 1986: The Human Skeleton in Forensic Medicine. Charles $C$. Thomas, Springfield.

22. Uthman, A. T., Al-Rawi, N. H., \& Al-Timimi, J. F. (2012). Evaluation of foramen magnum in gender determination using helical CT scanning. Dentomaxillofacial Radiology, 41(3), 197-202.

23. Ukoha, U., Egwu, O. A., Okafor, I. J., Anyabolu, A. E., Ndukwe, G. U., \& Okpala, I. (2011). Sexual dimorphism in the foramen magnum of Nigerian adult. Int J Biol Med Res, 2(4), 878-881.

24. Gapert, R., Black, S., \& Last, J. (2009). Sex determination from the foramen magnum: discriminant function analysis in an eighteenth and nineteenth century British sample. International Journal of Legal Medicine, 123(1), 25-33.

25. Scheuer, L, Black, S. (2000). Developmental Juvenile Osteology. London: Academic Press.

26. Gruber, P., Henneberg, M., Böni, T., \& Rühli, F. J. (2009). Variability of human foramen magnum size. The Anatomical Record: Advances in Integrative Anatomy and Evolutionary Biology, 292(11), 1713-1719.

27. Murshed, K. A., ÇIÇEKCİBAŞI, A. E., \& TUNCER, I. (2003). Morphometric evaluation of the foramen magnum and variations in its shape: a study on computerized tomographic images of normal adults. Turkish Journal of Medical Sciences, 33(5), 301-306.

28. Zaidi, S. H., \& Dayal, S. S. (1988). Variations in the shape of foramen magnum in Indian skulls. Anatomischer Anzeiger, 167(4), 338-340.

29. Govsa, F., Ozer, M. A., Celik, S., \& Ozmutaf, N. M. (2011). Three-dimensional anatomic landmarks of the foramen magnum for the craniovertebral junction. Journal of Craniofacial Surgery, 22(3), 1073-1076.

30. Catalina-Herrera, C. J. (1987). Study of the anatomic metric values of the foramen magnum and its relation to sex. Cells Tissues Organs, 130(4), 344-347.

31. Kanchan, T., Gupta, A., \& Krishan, K. (2013). Craniometric analysis of foramen magnum for estimation of sex. International journal of medical, Health, biomedical and pharmaceutical engineering, 7(7), 111-3.

32. Uysal, S. E. L. M. A., Gokharman, D., Kacar, M., Tuncbilek, I., \& Kosar, U. (2005). Estimation of sex by 3D CT measurements of the foramen magnum. Journal of Forensic Science, 50(6), JFS2005058-5.

33. İlgüy, D., İlgüy, M., Ersan, N., Dölekoğlu, S., \& Fişekçioğlu, E. (2014). Measurements of the foramen magnum and mandible in relation to sex using CBCT. Journal of forensic sciences, 59(3), 601-605.

34. Göçmez, C., Göya, C., Hamidi, C., Kamasak, K., Yilmaz, T., Turan, Y., \& Ceviz, A. (2014). Threedimensional analysis of foramen magnum and its adjacent structures. Journal of Craniofacial Surgery, 25(1), 93-97.

35. Ciaffi, R., Gibelli, D., \& Cattaneo, C. (2011). Forensic radiology and personal identification of unidentified bodies: a review. La radiologia medica, 116(6), 960-968.

36. Abdel-Karim, R. I., Housseini, A. M., \& Hashish, R. (2015). Adult sex estimation using ThreeDimensional Volume Rendering Multislice Computed Tomography of the foramen magnum and occipital condyles: A study in Egyptian population. IJAR, 3, 1212-1215. 